\title{
Erratum to: Experimental syntax and the variation of island effects in English and Italian
}

\author{
Jon Sprouse ${ }^{1}$ Ivano Caponigro ${ }^{2}$ Ciro Greco ${ }^{3}$. \\ Carlo Cecchetto ${ }^{4}$
}

Published online: 2 June 2015

(C) Springer Science+Business Media Dordrecht 2015

\section{Erratum to: Nat Lang Linguist Theory (2015) \\ DOI 10.1007/s11049-015-9286-8}

A number of examples were published with errors. Please find the correct examples in this erratum.

(6) WH ISLAND (Rizzi 1982:50, ex. 6)

Tuo fratello, a cui $_{1}$ mi domando che storie $_{2}$ abbiano your brother, to whom 1 to_myself ask.1SG what stories 2 have.SUBJ.3PL raccontato $\_2 \ldots 1$, era molto preoccupato.

told was very worried

'Your brother, who I wonder what stories they told, was really worried.'

The online version of the original article can be found under doi:10.1007/s11049-015-9286-8.

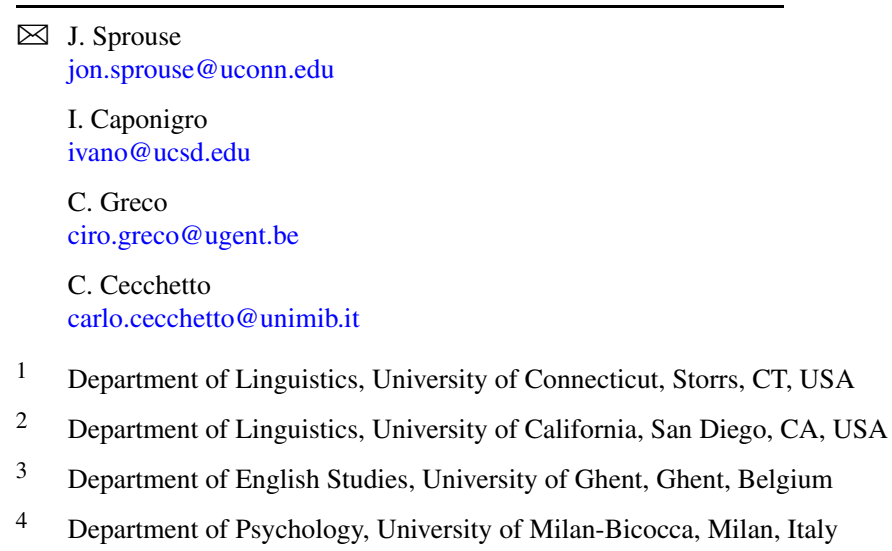


(9) ADJUNCT ISLAND

*In campo c'è un giocatore con il quale ti dovrebbero dare in field there's a player with the whom to_you should.3PL give istruzioni chiare [se gli altri giocatori saranno scorretti _ ]. instructions clear if the other players be.FUT.3PL unfair 'There's a player playing in the field towards whom they should give you clear instructions if the other players are unfair.'

\section{COMPLEX NP ISLANDS}

a. Who _ heard that Jeff baked a pie?

b. What did you hear that Jeff baked __?

c. Who _ heard [the statement that Jeff baked a pie]?

d. What did you hear [the statement that Jeff baked __]?

(15) SUBJECT ISLANDS

a. What do you think the gift prompted _ ?

b. What do you think _ prompted the rumor?

c. Who do you think [the gift from the lobbyist] prompted the rumor about__?

d. Who do you think [the gift from _ ] prompted the rumor about the Senator?

(19) SubJECT ISLANDS

a. I voted for the congressman who you think the lobbyist offended

b. I voted for the congressman who you think _ offended the lobbyist.

c. I voted for the congressman who you think [the gift from the lobbyist] prompted the rumor about

d. I voted for the congressman who you think [the gift from __] prompted the rumor about bribery.

(21) WHETHER ISLANDS

a. Chi _ pensa che io abbia letto il libro? who thinks that I have.SUBJ.SG read the book 'Who thinks I read the book?'

b. Cosa pensi che io abbia letto __?

what think.2SG that I have.SUBJ.SG read 'What do you think I read?'

c. Chi_si chiede [se io abbia letto il libro]? who to_himself asks if I have.SUBJ.SG read the book 'Who wonders if I read the book?'

d. Cosa ti chiedi [se io abbia letto__]?

what to_yourself ask.2SG if I have.SUBJ.SG read

'What do you wonder if I read?' 


\section{COMPLEX NP ISLANDS}

a. Chi_ ha affermato che io avrei rubato una macchina? who has claimed that I have.COND.1SG stolen a car 'Who claimed that I stole a car?'

b. Cosa hai affermato che io avrei rubato _ ? what have.2SG claimed that I have.COND.1SG stolen 'What did you claim that I stole?

c. Chi _ ha fatto [l'affermazione che io avrei rubato una who has made the-claim that I have.COND.1SG stolen a macchina]?

car

'Who made the claim that I stole a car?'

d. Cosa hai fatto [l'affermazione che io avrei what have.2SG made the-claim that I have.COND.1SG rubato __]?

stolen

'What did you make the claim that I stole?'

\section{(23) SUBJECT ISLANDS}

a. Chi pensi che il quadro raffiguri _ ? who think.2SG that the painting depict.SUBJ.SG 'Who do think that the painting portrays?'

b. Chi pensi che _ abbia dipinto il quadro? who think.2SG that have.SUBJ.SG painted the painting 'Who do you think has painted the painting?'

c. Di chi pensi che [il quadro di Maria] raffiguri la of who think.2SG that the painting of Maria depict.SUBJ.SG the nascita __?

birth

'Who do you think Maria's painting depicts the birth of?'

d. Dichi pensi che [il quadro _ ] raffiguri la nascita di of who think.2SG that the painting depict.SUBJ.SG the birth of Venere?

Venus

'Who do you think the painting of depicts the birth of Venus?'

(24) ADJUNCT ISLANDS

a. Chi _ dice che io abbia_usato il cellulare in classe? who says that I have.SUBJ.SG used the cell-phone in class 'Who says that I used my cell phone in class?'

b. Cosa dici che io abbia usato _ in classe? what say.2SG that I have.SUBJ.SG used in class 'What do you say that I used in class?'

c. Chi_si infuria [se uso il cellulare in classe]? who himself infuriates if use.1SG the cell-phone in class 'Who is going to get infuriated if I use my cell phone in class?' 
d. Cosa ti infuri [se uso _ in classe]?

what yourself infuriate. $2 \mathrm{SG}$ if use. $1 \mathrm{SG}$ in class

'What are you going to get infuriated if I use in class?'

\section{COMPLEX NP ISLANDS}

a. Ho telefonato all'uomo a cui hai fatto notare have.1SG phoned to_the man to whom have.2SG made notice che Andrea ha un atteggiamento ostile verso di noi. that Andrea has an attitude hostile towards of us 'I called the man you pointed out to that Andrea has a hostile attitude towards us.'

b. Ho telefonato all'uomo verso il quale hai fatto have.1SG phoned to_the man towards the whom have.2SG made notare che Andrea ha un atteggiamento ostile notice that Andrea has an attitude hostile 'I called the man towards whom you pointed out that Andrea has a hostile attitude.'

c. Ho telefonato all'uomo a cui hai fatto notare have.1SG phoned to_the man to whom have.2SG made notice [il fatto che Andrea ha un atteggiamento ostile verso di noi]. the fact that Andrea has an attitude hostile towards of us 'I called the man you pointed out to the fact that Andrea has a hostile attitude towards us.'

d. Ho telefonato all'uomo verso il quale hai fatto have.1SG phoned to_the man towards the whom have.2SG made notare [il fatto che Andrea ha un atteggiamento ostile _ ] notice the fact that Andrea has an attitude hostile 'I called the man towards whom you pointed out the fact that Andrea has a hostile attitude.'

\section{ADJUNCT ISLANDS}

a. Hanno intervistato il manager a cui ho detto _ che have.3PL interviewed the manager to whom have.1SG said that Andrea ha fatto nuove rivelazioni su di lui. Andrea has made new revelations on of him 'They interviewed the manager who I told that Andrea made new revelations about him.'

b. Hanno intervistato il manager su cui mi hanno detto have.3PL interviewed the manager on whom to_me have.3PL said che Andrea ha fatto nuove rivelazioni that Andrea has made new revelations 'They interviewed the manager they told me that Andrea has made new revelations about.' 
c. Hanno intervistato il manager a cui abbasseranno lo have.3PL interviewed the manager to whom lower.FUT.3PL the stipendio _ _ [se Andrea farà nuove rivelazioni]. stipend if Andrea make.FUT.3SG new revelations 'They interviewed the manager whose salary they will lower if Andrea makes new revelations.'

d. Hanno intervistato il manager su cui ci abbasseranno lo have.3PL interviewed the manager on whom to_us lower.FUT.3PL the stipendio [se Andrea farà nuove rivelazioni _ ]. stipend if Andrea make.FUT.3SG new revelations 'They interviewed the manager who they will lower our salary if Andrea makes new revelations on.' 